\title{
The impact of the EU Emissions Trading System on low- carbon technological change: the empirical evidence
}

\author{
Teixidó, J. J. \\ (Universitat de Barcelona, Dept.of Applied Economics-Public Policy) \\ Verde S.F. \\ (European University Institute, Florence School of Regulation-Climate) \\ Nicolli F. \\ (Università di Ferrara, Dept. Economics and Management)
}

\begin{abstract}
This paper reviews the empirical literature analysing the effects of the EU Emissions Trading System (EU ETS) on low-carbon technological change. The emerging evidence is assessed, with references to both relevant economic concepts and the evolving regulation of the EU ETS through time. The two most robust indications of the literature are: a) the EU ETS appears to have been more effective in stimulating innovation of low-carbon technologies rather than their adoption; and $b$ ) free allocation (grandfathering) tended to hamper low-carbon investments in Phases I (2005-2007) and II (2008-2012). However, a complete general picture of the impact of the EU ETS on low-carbon technological change is missing. The main gap regards the lack of empirical evidence for Phase III (2013-2020). Especially econometric studies are few, due to the lack of suitable databases accessible to researchers - a problem that the relevant public authorities are urged to address. Thanks to the recent reforms of the EU ETS, the incentives for innovation and adoption of low-carbon technologies are probably stronger today than ever before.
\end{abstract}

Keywords: EU ETS, low-carbon technological change, innovation incentives, free allocation, empirical evidence

\footnotetext{
Acknowledgements

The work leading to this study was co-financed by the EU LIFE Programme of the European Commission - Grant Agreement LIFE15 GIC/IT/000051 LIFE SIDE. This paper reflects only the authors' view and the Agency is not responsible for any use that may be made of the information it contains.
} 


\section{Introduction}

As time ticks away for drastically reducing global greenhouse gas (GHG) emissions, low-carbon technological change is ever more important for meeting future emissions reduction targets and minimising the cost of the effort. The EU, which has been a leader in the fight against climate change for over two decades, is committed to achieving carbon neutrality by 2050 (European Commission, 2018), in line with the Paris Agreement objective to keep the global temperature increase to "well below $2^{\circ} \mathrm{C}$ and pursue efforts to keep it to $1.5^{\circ} \mathrm{C}$ ". Since its adoption, in 2005, the EU Emissions Trading System (EU ETS) has been the cornerstone of the strategy for decarbonising the EU's economy and the flagship of EU climate policy. The EU ETS is thus expected to have a central role in inducing lowcarbon technological change as needed. However, whether and how the EU ETS plays this role is in fact not obvious, as many are the factors internal and external to the system to consider.

The EU ETS imposes a cap on total emissions of carbon dioxide, nitrous oxide and perfluorocarbons from over 11,000 heavy energy-using and electricity-generating installations and aircrafts, covering about $45 \%$ of the EU's overall GHG emissions. The cap, and with it the emissions, decline over time. At the end of the current trading period, which is Phase III (2013-2020), the cap will reach a level $21 \%$ below that of 2005 emissions; by 2030, the final year of Phase IV (2021-2030), emissions will have decreased by at least $43 \%$ relative to the same year. Simply described, the cap of an emissions trading system (ETS) determines the supply of emission allowances, whereas the demand for emission allowances depends on output levels and emission intensities of regulated entities. The interplay between demand and supply determines the dynamics of the price of emission allowances, a.k.a. the carbon price. In theory, the carbon price established by an ETS guarantees that the cap is met at minimum cost, meaning that the ETS is cost-effective. In practice, there are different reasons (including transaction costs, market power, investors' myopia and excessive discounting, among others) for which the carbon price may deviate from the optimal path, in which case the ETS is not costeffective. ${ }^{1}$

The EU ETS is a sophisticated policy instrument whose regulation has evolved considerably over the years, partly reflecting a learning-by-doing process and partly in response to unanticipated events. In 2009, the first major reform of the EU ETS, with effect from Phase III, made the system significantly more efficient than in Phases I (2005-2007) and II (2008-2012) through both its centralisation and a whole new set of rules for allowance allocation. ${ }^{2}$ At the very same time, however, Europe was hit by the most serious economic crisis since the Great Depression, which for the EU ETS meant a sharp decline in the demand for emission allowances. In addition to the fall in production, the supply-demand imbalance in the allowance market was compounded by the inflow of international credits issued under the Kyoto Protocol's Clean Development Mechanism and Joint Implementation, effectively increasing

\footnotetext{
${ }^{1}$ For a theoretical analysis of how an ETS should be evaluated, see Fuss et al. (2018).

${ }^{2}$ For an account of the regulatory changes of the EU ETS through the trading periods, with a focus on allocation rules, see Verde et al. (2019).
} 
allowance supply, and by effective renewable energy policies carried out by members states, resulting in further reduced allowance demand. The persistent excess supply, or market surplus, meant that the price of emission allowances stayed low for several years. As the level of carbon prices is the first determinant of low-carbon investment decisions, most analysts would probably agree that low carbon prices have been the main problem faced by the EU ETS since its inception. Steps were taken to address the market surplus. The surplus was first tackled through the withdrawal - originally intended to be temporary ("backloading") - of 900 million allowances and, then, in a structural way with the establishment of the Market Stability Reserve (MSR) ${ }^{3}$. Moreover, the reform for Phase IV (European Parliament and Council, 2018) has, among other things, tightened allowance supply further and enhanced financial support for low-carbon investments through dedicated funds.

Given the importance of low-carbon technological change for attaining sustainable economic prosperity and the importance of the EU ETS - still the world's largest ETS in operation - as a policy supposed to contribute to that end, empirical analyses examining whether and how the EU ETS fulfilled this expectation are valuable. This paper reviews the empirical literature on the subject, assessing its findings and limitations. The review aims to cover all relevant studies published in specialised journals or as working papers up until December 2018.

The rest of the paper is organised as follows. Section 2 lays out the theoretical background of the review. Section 3 presents the studies. Section 4 discusses the emerging evidence. Section 5 concludes.

\section{Theoretical background}

This section recalls a few important concepts for evaluating the impact of an ETS, such as the EU ETS or other similar systems, on low-carbon technological change. We focus on: $a$ ) the distinction between innovation and adoption of low-carbon technologies as different responses to carbon pricing; $b$ ) the main properties of an ETS for its ability to spur low-carbon technological change; and $c$ ) the ways in which free allocation of emission allowances may affect low-carbon technological change.

\subsection{Innovation vs adoption}

In the wide and diverse literature on technological innovation, the word "innovation" can mean different things. Notably, it may refer to the process of technological change, encompassing the invention of a novel production process or product, its implementation and subsequent diffusion through progressive adoption. Or, it may more narrowly refer to the invention of a novel production process or product. The terminology of innovation is not more univocal in the more specific domain of environmental

\footnotetext{
${ }^{3}$ The MSR (European Parliament and Council, 2015) is a rule-based mechanism that limits the excess supply and excess demand of emission allowances. By introducing some flexibility in allowance supply, the MSR is intended to mitigate the impacts on the carbon market of macroeconomic shocks and, for that matter, of any unforeseen event or development affecting allowance demand. The MSR has started operating in January 2019. For in-depth analyses of the economics of the MSR, the reader is referred to the dedicated special issue of the Journal of Environmental Economics and Management (Hepburn et al., 2016).
} 
innovation, which is innovation benefiting the environment. As a matter of fact, different definitions of "eco-innovation" add to ambiguity (Ekins, 2010). For example, the concept of eco-innovation is sufficiently wide to include adoption of a technology already used by others, which is, therefore, new for the acquiring firm ("new-to-the-firm") but not for the world ("new-to-the-market") (Kemp, 2010; Kemp and Pontoglio, 2011). In this paper, innovation is intended in the narrower sense just specified. ${ }^{4}$

With regard to technological change as a process that can be influenced by economic policy, John Hick's induced innovation hypothesis (IIH) underpins the idea that carbon pricing, whether in the form of carbon taxation or emissions trading, can spur novel low-carbon technologies. The IHH postulates that an increase in the relative price of a production factor spurs inventions aimed at reducing its use (Hicks, 1932). Considering carbon as a production factor, the IIH applies to carbon pricing. ${ }^{5}$ Of course, investing in $R \& D$ is not the only way in which a firm may respond to carbon pricing. Most of the time, adopting an already existing technology will be the best option for minimising compliance costs. ${ }^{6}$ From the policymaker perspective, however, only innovation (and not adoption) expands the technology set (Calel, 2018). This distinction is central in the context of climate change mitigation, as both innovation and diffusion (through adoption) of low-carbon technologies are needed to drastically reduce emissions.

\subsection{Key properties of an ETS: stringency and predictability}

Johnston et al. (2010) analyse the most important characteristics, or properties, of environmental policies for stimulating invention and diffusion of green technologies. By nature, emissions trading meets the highest standards for three of the five characteristics identified by the authors: flexibility, incidence and depth. ${ }^{7}$ The same is not true for the other two properties, which are stringency and predictability. Whether or, rather, to what extent an ETS is stringent or predictable, depends on its specific design.

The stringency of an environmental policy refers to the ambition of its (explicit or implicit) target relative to the alternative ("baseline") scenario without the policy. For an ETS, this means how stringent the cap is relative to the total amount of emissions that would be produced if the ETS was not there. Since counterfactual emissions are not observed (they can only be estimated), the price of emission allowances, as an indicator of their scarcity, is a proxy for the stringency of an ETS. In general, the empirical literature clearly supports the hypothesis that a more stringent environmental policy gives economic agents stronger incentives to search for ways to avoid compliance costs, thereby promoting technological change (Barbieri et al., 2016).

\footnotetext{
${ }^{4}$ Jaffe et al. (2003) provide a thorough analysis of the literature on environmental innovation produced until then. For a comprehensive review of the empirical literature on environmental policy and innovation published during the past decade, see Popp (2019).

${ }^{5}$ The applicability of the IIH is general, beyond market-based policies and the environmental policy domain.

${ }^{6}$ The outcomes of R\&D investments are generally highly uncertain (Scherer and Harhoff, 2000).

7 "Flexibility" refers to whether the policy encourages novel solutions for reducing the pollutant; "incidence" refers to how closely the policy targets the pollutant; and "depth" refers to whether the policy provides continuous incentives to develop technologies ever more effective in reducing the pollutant.
} 
The predictability of an environmental policy refers to the level of (un)certainty with which economic agents can expect the policy and its effects to unfold in the future. As technological change involves investment decisions, uncertainty can hamper technological change by affecting investors' expectations. Different types of uncertainty exist, however, with potentially different implications for technological change. With specific reference to an ETS, Hoffman et al. (2008) provide a taxonomy for different types of uncertainty. The authors first distinguish between regulatory and regulation-induced uncertainty. Regulatory uncertainty concerns: $a$ ) the basic direction of the ETS (related to, e.g., future emissions reduction targets, the scope of the system, changes in international climate policy) and its very existence; $b$ ) the rules for allowance allocation; $c$ ) the implementation process (e.g., allocation delays); and $d$ ) the interdependence with other policies. Regulation-induced uncertainty, by contrast, regards the state of the non-regulatory environment. For example, it can be uncertainty about competitors' strategies in the face of regulatory uncertainty or about the price of emission allowances. While regulatory uncertainty is considered detrimental to technological change, the same does not necessarily apply to regulation-induced uncertainty.

\subsection{Free allocation and technological change}

In an ETS, the emission allowances can be distributed to the regulated entities $a$ ) for free, in the form of grandfathering, benchmarking or output-based allocation, $b$ ) through auctions, or $c$ ) a mix of these methods. ${ }^{8}$ Minimising the risk of causing market share losses to the advantage of foreign competitors and, thereby, minimising the risk of carbon leakage ${ }^{9}$, is the economic rationale for using free allocation.

Among the most debated questions on the economics of emissions trading are whether grandfathering leads to output and emissions levels different from those achieved under auctioning (or a carbon tax) and, related, whether it alters the impact of the policy on technological change by affecting investment decisions. The standard answer is that the initial allocation makes no difference in these respects (Montgomery, 1972; Hahn and Stavins, 2011; Requate and Unold, 2003). This conclusion, however, rests on several assumptions about markets' structure and firms' behaviour. Among others, a key assumption is that firms fully value the opportunity cost of using free allowances for compliance ${ }^{10}$ in the same exact way as if it was a real cost. Increasingly, this assumption has been questioned in light

\footnotetext{
${ }^{8}$ With grandfathering, allowances are allocated in proportion to historical emissions. With benchmarking, allowances are allocated according to performance indicators. In practice, allocations are determined by multiplying the benchmarks (expressed in terms of emissions per unit of output) by recent output levels. With output-based allocation, allowances are allocated in proportion to current production levels.

${ }^{9}$ The displacement of GHG emissions due to differences in the stringency of climate mitigation policies is called carbon leakage. There are three main channels through which unilateral climate policy can result in carbon leakage: the trade balance (short-term impact), foreign direct investments (long-term impact) and changes in international fossil fuel prices. Deterioration of international competitiveness due to climate policy activates the first two channels. The third channel, by contrast, can come into play if the region strengthening its climate policy makes up a significant share of global fossil fuels demand.

${ }^{10}$ Since they have market value, using (preallocated) allowances for compliance carries an opportunity cost equal to the revenue that would be earned if (the corresponding emissions were avoided and) the allowances were sold.
} 
of insights from behavioural economics, pointing to a negative impact of free allocation on low-carbon technological change (Venmans, 2016). ${ }^{11}$ The same question applies to benchmarked allocation. The very purpose of benchmarking, however, is to promote low-carbon technological change by rewarding early movers investing in low-carbon technologies (Zipperer et al., 2017).

The literature identifies at least three other ways in which free allocation may alter the impact of an ETS on low-carbon technological change. One is the case of so-called new-entrant provisions, whereby a new plant entering the system is entitled to an allowance endowment for the duration of the trading period. The rationale for such arrangement - present in the EU ETS, not in other ETSs - is not to put new entrants at a disadvantage relative to the incumbents. However, the endowment could potentially change the relative convenience of alternative investments, thus affecting the investment decision. Unless allocations are determined on a fuel-neutral basis, allowance endowments to new entrants introduce a bias in favour of more emission-intensive investments (Åhman et al., 2007; Ellerman, 2008; Flues and van Dender, 2017). The second case is the situation where innovation or adoption of a low-carbon technology, by a firm holding a significant share of the allowance market, would result in a reduction of the allowance price (Fisher et al., 2003). In this case - unlikely in the EU ETS given the low concentration of the allowance market -, free allocation may hamper low-carbon technological change because the price drop would reduce the value of the allowances hold by the firm and, hence, the convenience of the investment. The third case - not applicable to the EU ETS so far refers to output-based allocation. In contrast to the previous cases, here low-carbon technological change may be strengthened due to greater production (output-based allocation effectively subsidises production) and higher allowance prices (Rosendahl and Storrøsten, 2015).

\section{The empirical evidence}

There are several empirical studies examining the effects of the EU ETS on firms' innovation or adoption of low-carbon technologies. Our search led to the identification of 22 such works, which here are first divided into two broad groups: the studies using econometrics (7) and those providing qualitative or descriptive analyses (15). In addition to this literature, five econometric studies provide evidence on the effects of the EU ETS on emission intensity of regulated manufacturing firms. Though not focused on technological change, these studies are potentially relevant in that variations in emission intensity may reflect changes in the technologies used.

The literature review below varies in format. In Section 3.1, the econometric studies focused on low-carbon technological change are described in detail, one-by-one. The literature providing evidence on emission intensity is summarised in the same section, but in a more concise way. In Section 3.2, the non-econometric studies are combined together in a single narrative.

\footnotetext{
${ }^{11}$ With reference to the EU ETS, Ellerman (2015) includes opportunity costs among the issues yet to be analysed seriously.
} 


\subsection{Econometric literature}

\subsubsection{Effects on low-carbon technological change}

Calel and Dechezleprêtre (2016) estimate the impact of the EU ETS on low-carbon patenting. It is a study that stands out in the literature for at least four reasons. First, patent counts, while not without shortcomings, ${ }^{12}$ are generally considered one of the most appropriate innovation indicators (Hagedoorn and Cloodt, 2003). Second, the firms in the estimation sample operate as many as $80 \%$ of all EU ETS installations. Third, the approach used, namely difference-in-differences (DiD), offers a clear-cut causal interpretation of the estimated effect. ${ }^{13}$ Fourth, the authors find that the EU ETS was effective in spurring low-carbon technology innovation, more so than other studies show or suggest: it is estimated that the EU ETS caused an increase of up to $36 \%$ in the number of low-carbon patents granted to regulated firms, over 2005-2009. Other relevant results are: a) that no evidence of an indirect innovation effect on non-regulated firms is found; and $b$ ) that the surge in the total number of low-carbon patents observed over the study period was primarily driven by rising energy prices.

Martin et al. (2013) is a second important econometric study investigating the determinants of low-carbon innovation, here measured by any $R \& D$ activity aimed at curbing emissions or energy consumption or at developing products that can help customers reduce their emissions. It uses primary data from interviews conducted in 2009 with the managers of 770 manufacturing firms in six European countries. The study finds several interesting results. First, the responses indicate that most firms engaged in climate-related innovation, and that this effort was focused on process innovation rather than product innovation. Crucially, however, no statistically significant difference is found between firms regulated by the EU ETS and non-regulated ones. Second, significant differences in the propensity to innovate were found across sectors and countries. Third, low-carbon innovation is positively associated with firms' expectations about the stringency of their future allocation. Fourth, firms positioned just below the sectoral thresholds for receiving free allowances in Phase III $^{14}$ engaged more strongly in low-carbon innovation. This last result is presented as evidence of free allocation having a causal negative effect on low-carbon innovation.

Schmidt et al. (2012a) analyse the effects of the EU ETS and long-term emission reduction targets, as they are perceived (rather than as they are according to objective metrics), on both investments in technology adoption and in R\&D. The study is based on interviews with managers of 65 electricityproducing firms and 136 firms providing technology for electricity generation, in seven European

\footnotetext{
${ }^{12}$ Not all innovations are patented, not all patented innovations are eventually adopted.

${ }^{13}$ Typically, in the studies using the $\mathrm{DiD}$ approach, regulated firms are first paired through statistical matching with similar non-regulated counterparts. The model for the variable of interest is then fitted, including a binary regressor indicating whether the firm participates in the EU ETS. The coefficient of this variable measures the effect of the EU ETS. For a technical overview of this and similar methods for policy evaluation, see Imbens and Wooldridge (2009).

${ }^{14}$ The thresholds in question are based on sectoral trade and carbon intensities.
} 
countries. The effects are measured by the respondents' answers to the questions about the intensity and the direction of innovation investments between two periods: 2000-2004 and 2005-2009. Among other results, the authors find evidence that not only did grandfathering of emission allowances hamper adoption of low-carbon technologies, but - as anticipated - new-entrant provisions promoted adoption of emitting technologies. A second important result is that long-term emission reduction targets are a powerful R\&D trigger.

Focusing on Sweden and again using the DiD approach, Lofgren et al. (2014) test for whether participation in the EU ETS stimulated investment in low-carbon technologies. The estimation sample comprises some 706 Swedish firms, of which 229 are in the EU ETS, from all regulated sectors, plus five control non-regulated sectors: the study covers the years 2000 to 2008. Conducting separate but similar analyses for investment below and over $€ 1$ million (in a year), respectively, different logit model specifications are estimated, with the outcome of interest being the probability of low-carbon investment. The main result is that statistically significant effects of the EU ETS are not found, either for small or for large investments ${ }^{15}$. Though limited to Swedish firms, the study also reports some insightful descriptive statistics on low-carbon investment within and outside the EU ETS sector ${ }^{16}$.

\section{[TABLE 1]}

Borghesi et al. (2015a) investigate whether the EU ETS affected the likelihood of climate-related investment (distinguishing between energy efficiency and emissions reduction as aims) undertaken by Italian manufacturing firms, 2006-2008. Firm-level probit models are estimated, using Eurostat's Community Innovation Survey as the primary data source. Several explanatory variables are considered: some internal to the firm, some external to the firm (still, firm-specific) and policy factors. The effects of the EU ETS are specifically captured: $a$ ) by a dummy variable identifying regulated sectors; and $b$ ) (in regressions limited to observations of regulated sectors) by a stringency indicator given by the ratio of sectoral emissions to allocated allowances. ${ }^{17}$ As expected, firms in regulated sectors are more likely to make climate-related investments. ${ }^{18}$ The allocation stringency indicator, however, turns out to be negatively correlated with innovation. The authors suggest that this result may be related to one or more

\footnotetext{
${ }^{15}$ Considering the frequency of investment decisions, the analysis would have probably benefited in a significant way from longer time coverage.

${ }^{16}$ For example, over the period 2002-2008, out of 229 regulated firms, 70 (i.e., almost a third) made some lowcarbon investment, 40 of which invested more than $€ 1$ million in a given year. With reference to the same firms, $46 \%$ of the large investments were in biofuels, $25 \%$ in district heating and $22 \%$ in energy efficiency; by contrast, over half of the small investments were in energy efficiency. The pulp and paper industry and the energy and heating sector had the highest shares of investors. Moreover, for regulated firms, fuel use was higher among investors compared to non-investors; the converse is true for non-regulated firms.

${ }^{17}$ Four regulated manufacturing sectors are analysed: coke and refining; ceramic and cement; paper and cardboard; and metallurgy.

${ }^{18}$ In the study, firms' participation in the EU ETS is defined at the sectoral level, however. This implies some measurement error, since not all firms in a regulated sector fall under the EU ETS.
} 
of the following: firms' anticipatory behaviour; sectoral idiosyncratic factors as well as reverse causality between allocation and innovation. Yet, further investigation is not undertaken due to data limitations.

Focusing on firms in the UK, Calel (2018) estimates the effects of the EU ETS on three outcomes: low-carbon patenting, low-carbon $R \& D$ expenditure and emission intensity. The estimation sample, assembled by linking administrative data with business surveys and regulatory records, comprises about 400 regulated firms and about as many non-regulated matches (i.e., non-regulated firms, very similar before the start of regulation), over the period 2000-2012. By comparing regulated firms after falling under the EU ETS and the respective non-regulated ones, the author infers that the EU ETS caused an average increase of low-carbon patents of about $25 \%$. An effect similar in size is found for low-carbon R\&D expenditure. By contrast, for emission intensity, no statistically significant difference between regulated and non-regulated firms is found. The results are interpreted as indicating that - contrary to what one may expect, based on past experiences with other ETSs - the EU ETS has been effective in spurring innovation of low-carbon technologies but not their diffusion, as this would have been reflected (had it taken place) in emission intensity improvements.

Compared to the studies above, Bel and Joseph (2018) address a partially different question, as they focus on the effect of allowance overallocation. The authors test for whether country-level oversupply of free allowances, as measured by allocated allowances exceeding verified emissions, had a negative effect on the number of filed low-carbon patents. Data for 28 countries are used, covering the period 2005-2012. Some interesting descriptive statistics are reported on the country distribution of low-carbon patents, showing Germany to be clearly the innovation leader in Europe. Country-level panel data models are then fitted for annual filed patent counts, explained by (lagged) allowance oversupply and a number of sectoral and economy-wide control variables (e.g., GDP, sectoral activity indices, R\&D spending, number of employees in the service sector, share of renewable energy). In all model specifications, allowance oversupply turns out to be negatively correlated with the number of patents.

\subsubsection{Effects on emission intensity}

Several econometric studies provide evidence on the effects of the EU ETS on firms' emission intensity. We focus on those dealing with manufacturing firms, as opposed to electricity producers, because variations in emission intensity of the former are more likely to reflect technology changes rather than fuel switching. ${ }^{19}$ This literature is homogeneous in multiple ways. Firstly, the results on emission intensity, usually measured by emissions divided by output or by employment, accompany findings on other effects of the EU ETS on firms' economic and environmental performance. More important, the approach typically involves firm- or plant-level quasi-experiments, typically of the DiD kind, whereby

\footnotetext{
${ }^{19}$ The empirical studies focusing on electricity generation highlight the effectiveness of the EU ETS in reducing emissions through fuel switching (from coal to gas). See, e.g., McGuinness and Ellerman (2008), Delarue et al. (2008) and Berghmans et al. (2014).
} 
the average effect of the EU ETS is inferred by comparing the outcome of interest for regulated firms or plants and for similar non-regulated ones. Further, as is true for all other works reviewed in this paper, these studies too are limited to Phase I or Phase II. The most salient element of differentiation is the country for which the analysis is conducted. A summary of the results of this literature follows.

Focusing on Germany, Petrick and Wagner (2014) estimate that the EU ETS reduced emission intensity of regulated manufacturing plants by $18 \%$ and $20 \%$ in Phase I and in the first half of Phase II, respectively. Further investigations indicate that these changes in emission intensity are mainly explained by optimisation of onsite heat generation and fuel switching. Thus, no evidence is found of significant technological upgrades. In a similar application to French manufacturing plants, Wagner et al. (2014) find a reduction of emission intensity by $8-12 \%$, again in the first three years of Phase II (not before). The effect vanishes, however, when the analysis is replicated at the firm level. Nil or very modest effects are found by other studies. Looking at regulated firms in Lithuania, Jaraite and Di Maria (2016) identify only a slight decrease in emission intensity for the year 2007 (not for 2006 or 2005), which appears to be mainly explained by the retirement of old physical assets. Klemetsen et al. (2016) find no statistically significant effects of the EU ETS on emissions intensity of regulated manufacturing plants in Norway, nor does Calel (2018) (as already said) for regulated firms in the UK.

\subsection{Non-econometric literature}

About two thirds of the studies dealing with the effects of the EU ETS on low-carbon technological change provide qualitative or descriptive analyses. We found 15 such works, of which 12 are based on primary information collected by the authors through ad-hoc interviews, typically with managers of regulated firms. These studies tend to be country- and sector-specific. Five of them focus on the electricity sector, five on the paper sector and one on the chemicals sector. The remaining four cover multiple sectors. Some of them are sufficiently narrow in scope to qualify as case studies.

Below, we first summarise the evidence from the studies exclusively looking at the electricity sector. We then turn to those analysing other sectors.

\subsubsection{Electricity sector}

Compared to other sectors, the impact of the EU ETS on technological change in the electricity sector has received more attention. There are multiple reasons for this: a) the electricity sector is by far the largest regulated sector, both in terms of emissions and number of installations; $b$ ) the electricity sector is expected to be fully decarbonised before any other major sector; c) certainly in the first years of the EU ETS, deployment of carbon capture and storage (CCS) for fossil fuel electricity generation was the main technology option in the EU's decarbonisation strategy; and $d$ ) the rules for free allocation in Phases I and II had particularly important implications for investment decisions concerning power plants. The most common research questions indeed relate to the consequences of specific allocation rules for new and closing installations and to the different factors influencing CCS deployment. 
The literature highlights the perverse incentives associated with the free allocation provisions for new installations entering the EU ETS. ${ }^{20}$ With reference to the first two trading periods, it is shown that new-entrant provisions (see Section 2.3) influenced investment decisions about the type of new plants to build. The emission allowances granted to new installations improved the economic attractiveness of investments in carbon-intensive electricity generation, notably coal-fired plants (Rogge et al., 2011b). Most important, these perverse incentives vanished as of Phase III, as electricity producers (with the exception of those in lower-income member states) ceased to receive free allowances. In fact, already before the start of Phase III, ${ }^{21}$ the expectation of auctioning is shown to have led to the cancellation of some planned investments in coal-fired power plants (Hervé-Mignucci, 2011).

The literature also clearly documents the initial interest in R\&D activities related to CCS. However, this interest did not eventually translate into actual CCS deployment for various reasons, notably the low level of carbon prices but also social acceptability problems encountered at the local level (Hoffman, 2007; Rogge and Hoffmann, 2010; Rogge et al., 2011b). ${ }^{22}$ In general, the expectation of sufficiently high carbon prices in the future and regulatory predictability are the elements that seem to matter most for $\mathrm{R} \& \mathrm{D}$ decisions.

Overall, the impact of the EU ETS on low-carbon technological change in the electricity sector, during the first two trading periods, appears to have been moderate. Most often, what impact there was came in the form of small-scale investments with short amortisation times (e.g., three to five years) improving the efficiency of existing conventional plants (Hoffmann, 2007). Table 2 summarises the main features and the main results of this literature.

\section{[TABLE 2]}

\subsubsection{Other sectors}

Considering the large number of sectors covered by the EU ETS and the limited size of the literature at hand (summarised in Table 3), the pulp and paper sector has received a remarkable amount of attention. The five non-econometric studies that specifically look at this sector are concordant in concluding that the EU ETS had only a modest effect, if any, in driving low-carbon technological change. Carbon prices were too low and allocations of free allowances too generous to affect investment decisions. A second common conclusion is that other market factors, notably the cost of raw materials and especially energy costs, were far more important factors in investment decisions. Gulbrandsen and Stenqvist (2013) document a case study of two Nordic pulp and paper companies that, because of the effect of the EU

\footnotetext{
${ }^{20}$ New-entrant and closure provisions characterise the EU ETS. Previous cap-and-trade schemes did not foresee such provisions (see, e.g., Ellerman et al., 2010).

${ }^{21}$ The new allocation rules for Phases III were set out by the second ETS Directive, in 2009: over three years before their entry into force. Thus, there was time for investor expectations and investment decisions to adapt to the new allocation regime.

${ }^{22}$ For a more in-depth discussion of why so far CCS projects have not been successful, see Ahman et al. (2018).
} 
ETS on electricity prices, show greater interest in investing in own electricity generation to reduce their dependence on wholesale electricity prices. According to Pontoglio (2008) and Gasbarro et al. (2013) relevant investments mainly consisted in the adoption of existing technologies for improving core process efficiency. Evidence consistent with the limited effect that the EU ETS seems to have had on technological change in the pulp and paper sector is provided by Fontini and Pavan (2014). Performing an index decomposition of the sectoral emission trends in Italy with 173 Italian plants, the authors show that technological change was never a relevant contributor to emission reductions. For Phase I, a compositional effect is found, whereby emissions slightly declined thanks to a shift toward less carbonintensive types of paper products. For the second trading period, the reduction in emissions was explained by diminished production - the effect of the economic crisis.

\section{[TABLE 3]}

The other non-econometric studies bring additional evidence that is largely consistent with the results discussed so far. Using information on production costs from four Portuguese companies in the chemicals sector, Tomas et al. (2010) show that the EU ETS did not significantly change production costs (thus providing no investment incentives), partly because - the authors argue - the allowances were grandfathered. Based on interviews with managers from the ceramics, lime and cement sectors, in Belgium, Venmans (2016) concludes that a) uncertainty about very low or very high carbon prices in the future and $b$ ) allowance overallocation were the main factors hindering low-carbon investments. Based on interviews with representatives of different industries in eight European countries, Borghesi et al. (2015b) investigate whether and how policies and market factors affected eco-innovation. The EU ETS turns out to have had a relatively more significant role in the electricity sector than in manufacturing sectors, inducing fuel switching and CCS-related activities. Based on questionnaires administered to regulated firms in Ireland, Anderson et al. (2010) find that significant low-carbon technological change occurred during Phase I. Substantial shares of the respondents stated that they had undertaken some technology changes as well as fuel switching and behavioural change. However, it is unclear to what extent these were effects of the EU ETS. Finally, Petsonk and Cozijnsen (2007) document a few cases of firms in the agriculture sector benefitting from different process innovations brought about by the EU ETS.

\section{Discussion}

Some important indications emerge from the literature presented. We focus on: $a$ ) the different effects of the EU ETS on innovation and on adoption of low-carbon technologies, and $b$ ) the negative effect of free allocation on low-carbon technological change. But first of all, let us consider the limitations of the literature. 


\subsection{The general picture is incomplete}

The empirical literature on the effects of the EU ETS on innovation and adoption of low-carbon technologies is significant in size and, taken together, offers some robust results. Nevertheless, it falls short of providing a complete picture of the impact of the EU ETS on low-carbon technological change. The main gap regards the lack of empirical evidence for the last six years or so, as none of the studies identified comes up to cover even the beginning of Phase III. This delay of empirical results is particularly unfortunate because major changes in the rules for allowance allocation, potentially affecting firms' investment decisions, came into operation in the third trading period. These changes, introduced by the second ETS Directive (European Parliament and Council, 2009), include: $a$ ) the switch from grandfathering to auctioning as default allocation method for the electricity sector, $b$ ) benchmarked allocation for all other sectors, plus $c$ ) progressive expansion of auctioning (free allocation shrinking from $80 \%$ in 2013 to 30\% in 2020) for those identified as not at risk of carbon leakage. These regulatory changes point to a potentially stronger impact of the EU ETS on low-carbon technological change during Phase III - all the more plausible given the evidence on the effects of free allocation in the previous trading periods (see below). On the other hand, again relative to Phases I and II, allowance prices have been lower most of the time, suggesting a weaker effect on low-carbon investments (Figure $1)$.

\section{[FIGURE 1]}

It is thus difficult to guess whether, in the period for which empirical evidence is missing, the EU ETS has had a greater or smaller impact on low-carbon technological change than it did in previous years. In this sense, the current situation is easier to interpret. The combination of Phase III allocation rules and - now - substantial carbon prices, which have much increased since the Reform for Phase IV was agreed, suggests that the incentives for innovation and adoption of low-carbon technologies are probably stronger today than ever before.

Other limitations of the literature are related to the small number of econometric studies and of sector-specific findings. The small number of econometric studies implies that there are few empirical results with statistical relevance, which is what allows drawing conclusions with some general validity. For this reason, econometric studies are usually of special interest and, consistent with this view, our summary of the econometric literature is more detailed than that of the non-econometric literature. This is not to say that econometric studies are superior to non-econometric ones in all respects. The second can offer important insights on, for example, agents' behaviour or specific situations, that the first are not able to capture through regression analysis. The scarcity of databases that are both suitable, meaning sufficiently large and with sufficiently detailed information on firms' investments, and usable or easily accessible for research purposes, is the main reason for the paucity of econometric works in this field. 
The small number of sector-specific findings implies that the existing evidence is not very granular at the sector level. Most results, especially those of econometric applications as they require sufficiently numerous observations for parameter identification, refer to aggregates of heterogeneous sectors. Notably, this is the case of estimated average effects for the regulated manufacturing sector, which in the given application may comprise several diverse subsectors, such as cement, steel, paper, glass, etc. With the exceptions of the electricity sector and of the pulp and paper sector, sector-specific evidence for the others is very limited or missing. This is a limitation of the literature because sectorspecific evidence can be useful, especially for informing policy adjustments.

\subsection{More innovation than adoption}

Despite said limitations, the existing literature gives a rather clear indication on how the EU ETS has affected low-carbon technological change. So far, the EU ETS appears to have been more effective in stimulating innovation of low-carbon technologies rather than their adoption. To our knowledge, Calel (2018) has been the first to note this type of asymmetry, even though his own measure of adoption (emission intensity improvement) is only a proxy. In any case, Calel's intuition and findings are confirmed by our examination of the literature.

Focusing on the econometric literature, Table 4 compares the direction of estimated effects of the EU ETS on innovation and on adoption of low-carbon technologies.

\section{[TABLE 4]}

In two out of three applications relevant to technology adoption, the effect of the EU ETS on investment in existing low-carbon technologies is not statistically significant. ${ }^{23}$ Borghesi et al. (2015a) find a positive effect, though it might be potentially affected by measurement error (see footnote 18). The situation is reversed for the effects on innovation. In four out of five applications, with low-carbon R\&D expenditure or low-carbon patent count as dependent variable, the effect of the EU ETS is positive and substantial in magnitude, especially for patenting. The interpretation of the same results can benefit from bringing into the picture those of the literature on emission intensity. For manufacturing firms, the effects on emission intensity range from moderate to - more often - nil. The very few studies investigating how identified emission intensity improvements were achieved indicate that the EU ETS mainly induced optimisation of energy use and fuel switching, rather than technology changes.

These findings invite at least two types of considerations. First, little to no effect of the EU ETS on adoption of low-carbon technologies is reason for some concern, as delayed action would normally result in higher costs over the long term. The very low carbon prices observed during most of Phase III

\footnotetext{
${ }^{23}$ In our "innovation vs adoption" comparison, emission intensity improvements are not considered because they may not exclusively reflect adoption of low-carbon technologies. This does not alter the conclusion about the observed asymmetry between innovation and adoption effects.
} 
add to this concern. On the other hand, the recent reforms of the system (the establishment of the MSR and the reform for Phase IV) have radically changed market expectations, as is reflected in the surge of allowance prices. Second, the effects on low-carbon innovation seem at odds with the results for emission intensity. One might expect that low-carbon innovation would eventually translate into lower emission intensity, which is not what the literature shows. What can explain this apparent discrepancy? An increase in low-carbon patenting may be quite an imperfect proxy for resulting emission reductions. Also, estimated average effects of the EU ETS on emission intensity may hide significant differences across sectors. In future, useful empirical research would more clearly identify the links between technological change and emission reductions.

\subsection{Free allocation: a brake on low-carbon technological change}

The effect of free allocation on technological change is a second important question on which the literature examined gives a rather clear indication. Namely, free allocation (grandfathering) tended to hamper low-carbon technological change in Phases I and II. The most general explanation is that regulated firms undervalue the opportunity cost of using their own free allowances as compared to the real cost of purchasing allowances on the market. As a result, through both operational and investment decisions, they end up abating fewer emissions than they would if they had fewer or no free allowances. ${ }^{24} \mathrm{~A}$ more specific mechanism whereby free allocation affected low-carbon technological change is that related to new-entrant provisions. The effect was salient in the electricity sector because, despite coal and gas can be close substitutes as fuels, allowance allocations for new installations were determined based on emissions rather than output (KWh).

While evidence on how free allocation affected technological change is rather clear, the caveat that this result refers to the first two trading period could not be overemphasised. Both the rules for free allocation and the volume of free allocation have changed drastically with Phase III. Notably: a) auctioning has become the default allocation method for the electricity sector (thus solving the issue of new-entrant provisions in that sector); $b$ ) while $95 \%$ and $90 \%$ of all allowances were allocated for free in Phases I and II, respectively, the same share has dropped to about 57\% (due to auctioning in the electricity sector and increasingly limited free allocation for the sectors not at risk of carbon leakage); c) the volume of free allowances has also shrunk because the EU ETS cap declines over time; and $d$ ) benchmarked allocation has replaced grandfathering, introducing a potentially important incentive for undertaking technology upgrades.

Moreover, in general, no definitive judgement on free allocation should be passed without considering the costs that may have been avoided thanks to free allocation. That is, one should also consider how free allocation performed with respect to its own purpose, which is minimising the risk

\footnotetext{
${ }^{24}$ For an analysis of the different ways in which the perception of free allowance allocations may lead to different investment decisions, the reader is referred to Venmans (2016).
} 
of carbon leakage. The relevant literature indicates that, certainly in the first two trading periods, the EU ETS had no significant negative effects on the competitiveness of regulated firms (Verde, 2018). In fact, not only was free allocation sufficiently generous to prevent negative competitiveness effects, but it also enabled regulated firms (with differences from sector to sector) to gain windfall profits - which is also controversial. However, while today it is safe to assume that there were margins for reducing free allocation in Phases I and II without consequences in terms of negative competitiveness effects, the same cannot be automatically extended to Phase III.

\section{Concluding remarks}

The review of the empirical literature on the effects of the EU ETS on low-carbon technological change has highlighted a few robust findings as well as limitations of the same evidence. Concerning the findings, we have stressed: $a$ ) the stronger effect of the EU ETS on low-carbon innovation rather than on adoption; and $b$ ) the negative effect of free allocation on low-carbon investments, in the first two trading periods. As of Phase III, both extensive auctioning and benchmarked allocation have strengthened the incentives for low-carbon investments. However, probably, the benefits of the new allocation regime were more than offset by very low allowance prices during most of Phase III. Recently, the establishment of the MSR mechanism and the Reform for Phase IV have addressed the problem of excessively low prices: the Reform by tightening the cap further, the MSR by (eventually) keeping allowance supply-demand imbalances within given boundaries. Though criticised by some for not being timely, the regulatory response has proved effective considering the evolution of allowance prices since early $2018 .^{25}$

Current and prospective allowance prices combined with progressively shrinking free allocation (due to the cap declining over time) call for enhanced financial support to low-carbon investments. Carbon pricing is gradually spreading around the world (World Bank and Ecofys, 2018), but to be sure the achievement of a de facto global carbon price (whether through cooperative processes or controversial border adjustments) is not guaranteed or close in time. Support to low-carbon investments, towards both innovation and adoption, is thus an increasingly important lever to counter competitiveness deterioration (by reducing emission intensity) and mitigate carbon leakage risk. ${ }^{26}$ Introduced as part of the Reform for Phase IV, the Innovation Fund and the Modernisation Fund promise to be useful tools in this sense. With specific reference to the Innovation Fund, many were the lessons learnt from the difficulties incurred with its predecessor NER300 ( $\AA$ hman et al., 2018; European

\footnotetext{
${ }^{25}$ Still, carbon prices currently prevailing in the EU ETS remain below the lower bound of the price range recommended by the High-Level Commission on Carbon Prices (2017), for 2020, to meet the $2^{\circ} \mathrm{C}$ objective of the Paris Agreement (US\$40-80/tCO 2 ).

${ }^{26}$ In presence of international spillovers, not only can low-carbon innovation mitigate carbon leakage risk, but it could also result in negative carbon leakage, that is, lower emissions overseas (Fischer, 2015; Gerlagh and Kuik, 2014).
} 
Commission, 2015, 2019), plus its size is expected to be almost five times as big, namely about $€ 10$ billion, compared to $€ 2.1$ billion.

As to the limitations highlighted by the literature review, the small number of econometric studies and the lack of results for the last few years have been stressed. At the root of the shortage of econometric studies is the scarcity of firm-level databases both suitable in terms of information content and accessible to researchers. Badly needed are especially firm-level data on climate-related investments, enabling analyses of the diffusion of low-carbon technologies in the economy. An ideal database would contain longitudinal data for both regulated and non-regulated firms, as this would facilitate econometric analyses identifying causal relationships. Administrative data and business surveys maintained by national statistical authorities already generate, or could generate, databases with such features. However, often access to these data for research purposes is not allowed or is heavily restricted for confidentiality reasons. Given the ever increasing importance of low-carbon technological change for society and, therefore, of monitoring whether and how the EU ETS or other policies affect it, EU and MS relevant authorities are urged to improve said data and, while ensuring confidentiality as needed, make them usable for research purposes.

\section{References}

Åhman, M., Burtraw, D., Kruger, J., and L. Zetterberg (2007), A Ten-Year Rule to guide the allocation of EU emission allowance, Energy Policy, 35(3), 1718-1730.

Åhman, M., Skjærseth, J. B., Eikeland, P.O. (2018), Demonstrating climate mitigation technologies: An early assessment of the NER300 programme, Energy Policy, 117, 100-107.

Anderson, B., Convery, F., Di Maria, C. (2010), Technological Change and the EU ETS: The case of Ireland, Economics Working Papers 10-06, Queen's Management School, Queen's University Belfast. 
Barbieri, N., Ghisetti, C., Gilli, M., Marin, G. and F. Nicolli (2016), A survey of the literature on environmental innovation based on main path analysis, Journal of Economic Surveys, 30(3), 596-623.

Bel, G. and S. Joseph (2018), Policy stringency under the European Union Emission trading system and its impact on technological change in the energy sector, Energy Policy, 117, 434-444.

Berghmans N., Chèze B., Alberola E. and J. Chevallier (2014), The CO2 emissions of the European power sector: economic drivers and the climate-energy policies' contribution, CDC Climat Research Working Paper No. 2014-17, CDC Climat Research.

Borghesi, S., Cainelli, G. and M. Mazzanti (2015a), Linking emission trading to environmental innovation: Evidence from the Italian manufacturing industry, Research Policy, 44, 669-683.

Borghesi, S., Crespi, F., D’Amato, A., Mazzanti, M., Silvestri, F. (2015b). Carbon abatement, sector heterogeneity and policy responses: Evidence on induced eco innovations in the EU, Environmental Science \& Policy, 54:377-388.

Calel, R. and Dechezleprêtre, A. (2016), Environmental policy and directed technological change: Evidence from the European carbon market, The Review of Economics and Statistics, 98(1), 173-191.

Calel, R. (2018), Adopt or innovate: understanding technological responses to cap-and-trade, CESifo Working Paper Series No. 6847.

Delarue, E., K. Voorspoels, and W. D'haeseleer (2008), Fuel Switching in the Electricity Sector in the EU ETS: Review and Prospective, Journal of Energy Engineering, 134(2), 40-46.

Ekins, P. (2010), Eco-innovation for environmental sustainability: concepts, progress and policies, International Economics and Economic Policy, 7, 267-290.

Ellerman, D. (2015), The EU ETS: what do we know and what we don't know, in: Gronwald, M. and B. Hintermann (eds.), Emissions trading as a policy instrument - Evaluation and prospects, CESifo Seminar Series, The MIT Press.

Ellerman, D. (2008), New Entrant and Closure Provisions: How do they Distort? The Energy Journal, $29,63-76$.

Ellerman, D., Convery, F. and C. de Perthuis (2010), Pricing carbon - The European Union Emissions Trading Scheme, Cambridge University Press.

European Commission (2015), Impact assessment accompanying the document Proposal for a Directive of the European Parliament and of the Council amending Directive 2003/87/EC to enhance cost-effective emission reductions and low-carbon investments, Commission Staff Working Document, Brussels, European Commission.

European Commission (2019), Impact assessment accompanying the document Commission Delegated Regulation supplementing Directive 2003/87/EC of the European Parliament and of the Council with regard to the operation of the Innovation Fund, Commission Staff Working Document, Brussels, European Commission.

European Parliament and Council (2009), Directive 2009/29/EC of the European Parliament and of the Council of 23 April 2009 amending Directive 2003/87/EC so as to improve and extend the greenhouse gas emission allowance trading scheme of the Community, Brussels, European Parliament and Council.

European Parliament and Council (2015), Decision (EU) 2015/1814 of the European Parliament and of the Council of 6 October 2015 concerning the establishment and operation of a market stability 
reserve for the Union greenhouse gas emission trading scheme and amending Directive 2003/87/EC, Brussels, European Parliament and Council.

European Parliament and Council (2018), Directive 2018/410 of the European Parliament and of the Council amending Directive 2003/87/EC to enhance cost-effective emission reductions and low-carbon investments, and Decision 2015/1814, Brussels, European Parliament and Council.

Fischer, C. (2015), Options for avoiding carbon leakage, in: Barrett, S., Carraro, C. and J. de Melo (eds.), Towards a workable and effective climate regime, CEPR Press, London.

Fischer, C., Parry, I.W.H. and W.A. Pizer (2003), Instrument choice for environmental protection when technological innovation is endogenous, Journal of Environmental Economics and Management, 45, 523-545.

Flues, F. and K. van Dender (2017), Permit allocation rules and investment incentives in emissions trading systems, OECD Taxation Working Papers, 33, OECD Publishing, Paris.

Fontini, F., Pavan, G. (2014), The European Union Emission Trading System and technological change: The case of the Italian pulp and paper industry, Energy Policy, 68, 603-607.

Fuss, S., Flachsland, C., Koch, N., Kornek, U., Knopf, B. and O. Edenhofer (2018), A framework for assessing the performance of cap-and-trade systems: insights from the European Emissions Trading System, Review of Environmental Economics and Policy, 12(2), 220-241.

Gasbarro, F., Rizzi, F., Frey, M. (2013), The mutual influence of Environmental Management Systems and the EU ETS: Findings for the Italian pulp and paper industry, European Management Journal, 31(1): 16-26.

Gerlagh, R. and O. Kuik (2014), Spill or leak? Carbon leakage with international technology spillovers: A CGE analysis, Energy Economics, 45, 381-388.

Goulder, L.H., and W.H. Parry (2008), Instrument choice in environmental policy, Review of Environmental Economics and Policy, 2(2), 152-174.

Gulbrandsen, L.H., and C. Stenqvist (2013), The limited effect of EU emissions trading on corporate climate strategies: comparison of a Swedish and a Norwegian pulp and paper company, Energy Policy, $56,516-525$

Hagedoorn, J. and M. Cloodt (2003), Measuring innovative performance: is there an advantage in using multiple indicators?, Research Policy, 32, 1365-1379.

Hahn, R.W. and R.N. Stavins (2011), The effect of allowance allocations on cap-and-trade system performance, Journal of Law and Economics, 54, S267-S294.

Hepburn, C., Neuhoff, K., Acworth, W., Burtraw, D. and F. Jotzo (2016), The economics of the EU ETS markets stability reserve, Journal of Environmental Economics and Management 80, 1-5.

Hervé-Mignucci, M. (2011), Operating and financial investments by European utilities over 2004-2009: what role for European mitigation policies?, CDC Climat Research Working Paper, N 2011 -9.

Hicks, J. (1932), The theory of wages, Macmillan \& Co., London.

High-Level Commission on Carbon Prices (2017), Report of the High-Level Commission on Carbon Prices, World Bank, Washington D.C. 
Hoffmann, V.H. (2007), EU ETS and Investment Decisions: The Case of the German Electricity Industry, European Management Journal, 25(6): 464-474.

Hoffmann, V.H., Trautmann, T. and M. Schneider (2008), A taxonomy for regulatory uncertainty application to the European Emission Trading Scheme, Environmental Science and Policy, 11, 712722.

Imbens, G.W. and J.M. Wooldridge (2009), Recent developments in the econometrics of program evaluation, Journal of Economic Literature, 47(1), 5-86.

Jaffe, A.B., R.G. Newell, and R.N. Stavins (2003), Technological change and the environment, in Mäler K.G. and J.R. Vincent (eds.), Handbook of Environmental Economics, (Vol.1), 461-516, Elsevier.

Jaraite J. and Di Maria, C. (2016), Did the EU ETS make a difference? An empirical assessment using Lithuanian firm-level data, The Energy Journal, 37(1), 1-23.

Johnstone, N., I. Haščič and M. Kalamova (2010), Environmental policy design characteristics and technological innovation: evidence from patent data, OECD Environment Working Papers, 16, OECD Publishing, Paris.

Kemp, R. (2010), Eco-innovation: definition, measurement and open research issues, Economia Politica, 27(3), 397-420.

Kemp, R. and S. Pontoglio (2011), The innovation effects of environmental policy instruments - A typical case of the blind men and the elephant?, Ecological Economics, 72, 28-36.

Klemetsen, M.E., Rosendahl, K.E. and A.L. Jacobsen (2016), The impacts of the EU ETS on Norwegian plants' environmental and economic performance, NMBU Working Paper 3/2016, Norwegian University of Life Sciences School of Economics and Business.

Löfgren, Á, Wråke, M., Hagberg T. and Roth, S. (2014), Why the EU ETS needs reforming: an empirical analysis of the impact on company investments. Climate Policy, 14(5), 537-558.

Martin, R., Muûls, M. and Wagner U. (2013), Carbon markets, carbon prices and innovation: Evidence from interviews with managers, Paper presented at the Annual Meetings of the American Economic Association, San Diego.

McGuinness, M. and A.D. Ellerman (2008), CO2 abatement in the UK power sector: evidence from EU ETS trial period, CEEPR Working Paper No. 2008-010, Center for Energy and Environmental Policy Research, Massachusetts Institute of Technology.

Montgomery, W.D. (1972), Markets in licenses and efficient pollution control programs, Journal of Economic Theory, 5, 395-418.

Nemet, G.F., Kraus, M. and V. Zipperer (2016), The valley of death, the technology pork barrel, and public support for large demonstration projects, DIW Discussion Paper 1601, Deutsches Institut für Wirtschaftsforschung.

Petsonk, A., Cozijnsen, J. (2007), Harvesting the Low-Carbon Cornucopia: how the European union emission trading system (EU-ETS) is spurring innovation and scoring results, Environmental Defense Fund.

Petrick, S. and U.J. Wagner (2014), The impact of carbon trading on industry: evidence from German manufacturing firms, Kiel Working Paper No.1912, Kiel Institute for the World Economy. 
Pontoglio, S. (2008), The role of environmental policies in the eco-innovation process: evidences from the European Union Emission Trading Scheme, Paper presented at DIME International Conference "Innovation, sustainability and policy", 11-13 September 2008, GREThA, University Montesquieu Bordeaux IV, France.

Popp, D. (2019), Environmental policy and innovation: a decade of research, NBER Working Paper Series, Working Paper 25631, Cambridge, Massachusetts.

Requate, T., and W. Unold (2003), Environmental policy incentives to adopt advanced abatement technology — will the true ranking please stand up?, European Economic Review, 47, 125-146.

Rogge, K. (2016), Reviewing the evidence on the innovation impact of the EU Emission Trading System, in: Weishaar, S.E., Research Handbook on Emissions Trading, Environmental Law Series, Cheltenham: Edward Elgar

Rogge, K.S. and V.H. Hoffmann (2010), The impact of the EU ETS on the sectoral innovation system for power generation technologies - Findings for Germany, Energy Policy, 38, 7639-7652.

Rogge, K.S., Schleich, J., Haussmann, P., Roser, A., Reitze, F. (2011a), The role of the regulatory framework for innovation activities: the EU ETS and the German paper industry, International Journal of Technology, Policy and Management, 11(3/4): 250 - 273.

Rogge, K.S., Schneider, M., Hoffmann, V.H., (2011b), The innovation impact of the EU Emission Trading System - Findings of company case studies in the German power sector, Ecological Economics, 70(3): 513-523.

Rosendahl, K.E. and H.B. Storrøsten (2015), Allocation of emission allowances: impacts on technology investments, Climate Change Economics, 6(3), 1550010.

Scherer, F.M. and D. Harhoff (2000), Technology policy for a world of skew-distributed outcomes, Research Policy, 29, 559-566.

Schmidt, T. S., Schneider, M., Rogge, K., Schuetz, M. J.A. and Hoffmann, V. H. (2012a), The effects of climate policies on the rate and direction of innovation: A survey of the EU ETS and the electricity sector, Environmental Innovation and Societal Transitions, 2, 23-48.

Schmidt, T.S., Schneider, M., Hoffmann, V.H. (2012b), Decarbonising the power sector via technological change - differing contributions from heterogeneous firms, Energy Policy, 43, 466-479.

Tomás, R.A.F., Ramôa Ribeiro, F., Santos, V.M.S., Gomes, J.F.P., and J.C.M. Bordado (2010), Assessment of the impact of the European CO2 emissions trading scheme on the Portuguese chemical industry, Energy Policy, 38(1), 626-632.

Venmans, F.M.J. (2016), The effect of allocation above emissions and price uncertainty on abatement investments under the EU ETS, In Journal of Cleaner Production, 126, 595-606.

Verde, S.F. (2018), The impact of the EU Emissions Trading System on competitiveness and carbon leakage, EUI Working Paper RSCAS 2018/53, European University Institute, Florence.

Verde, S.F., Teixido, J., Marcantonini, C. and X. Labandeira (2019), Free allocation rules in the EU Emissions Trading System: what does the empirical literature show? Climate Policy 19(4), 439-452.

Wagner, U., Muûls, M., Martin, R. and J. Colmer (2014), The causal effects of the European Union Emissions Trading Scheme: evidence from French manufacturing plants, Mimeo. 
World Bank and Ecofys (2018), State and trends of carbon pricing 2018 (May), World Bank, Washington DC.

Zipperer, V., Sato, M. and K. Neuhoff (2017), Benchmarks for emissions trading - general principles for emissions scope, Working Paper No. 287, Grantham Research Institute on Climate Change and the Environment, London School of Economics, London. 
Table 1 - Summary of econometric studies

\begin{tabular}{|c|c|c|c|c|c|c|c|c|c|c|}
\hline Study & Data & MS & P1 & $\mathbf{P 2}$ & $\mathbf{P 3}$ & $\begin{array}{l}\text { Sector (years } \\
\text { covered) }\end{array}$ & $\begin{array}{l}\text { Innovation } \\
\text { measurement } \\
\text { (Dependent Variable) }\end{array}$ & $\begin{array}{l}\text { Main variables of interest } \\
\text { (Independent Variable) }\end{array}$ & Method & Result \\
\hline $\begin{array}{l}\text { Calel and } \\
\text { Dechezleprêtre } \\
\text { (2016) }\end{array}$ & $\begin{array}{l}\text { Firm level data } \\
(80 \% \text { of EU-ETS } \\
\text { emission covered })\end{array}$ & $18 \mathrm{MS}$ & $\mathrm{X}$ & $\mathrm{X}$ & & $\begin{array}{l}\text { All sectors (2005- } \\
2009)\end{array}$ & Low-carbon Patents & $\begin{array}{l}\text { - Participation in the EU ETS } \\
\text { (dummy) }\end{array}$ & $\begin{array}{l}\text { Matched Difference- } \\
\text { in-Difference }\end{array}$ & $\begin{array}{l}\text { Positive effect of the EU ETS on the number of low-carbon patents } \\
(+36 \% \text { compared to counterfactual). } \\
\text { No effect of the EU ETS on third parties innovation (i.e. no indirect } \\
\text { effects). }\end{array}$ \\
\hline \multirow[t]{2}{*}{$\begin{array}{l}\text { Martin et al. } \\
\text { (2013) }\end{array}$} & \multirow{2}{*}{$\begin{array}{l}\text { Firm level data } \\
\text { ( } 770 \text { firms } \\
\text { interviewed) }\end{array}$} & \multirow[t]{2}{*}{$6 \mathrm{MS}$} & \multirow[t]{2}{*}{$\mathrm{X}$} & \multirow[t]{2}{*}{$\mathrm{X}$} & \multirow[t]{2}{*}{ (1) } & \multirow[t]{2}{*}{$\begin{array}{l}\text { Manufacturing } \\
\text { firms (2009) }\end{array}$} & \multirow[t]{2}{*}{ Low-carbon R\&D } & $\begin{array}{l}\text { - Participation in the EU ETS } \\
\text { (dummy) } \\
\text { - Expectation on ETS } \\
\text { stringency (cap and price) }\end{array}$ & $\begin{array}{l}\text { Multivariate linear } \\
\text { regression (OLS) }\end{array}$ & $\begin{array}{l}\text { Non-significant difference between EU ETS and non EU ETS firms } \\
\text { in inducing innovation. } \\
\text { Positive effect of expected stringency (on the cap) on R\&D } \\
\text { decisions. }\end{array}$ \\
\hline & & & & & & & & $\begin{array}{l}\text { - Exemption from permit } \\
\text { auction post-2012 (dummy) }\end{array}$ & $\begin{array}{l}\text { Regression } \\
\text { Discontinuity Design }\end{array}$ & Negative effect of free allowance allocation on innovation efforts. \\
\hline $\begin{array}{l}\text { Schmidt et al. } \\
\text { (2012a) }\end{array}$ & $\begin{array}{l}\text { Firm level data } \\
\text { (65 electricity } \\
\text { producers and } 163 \\
\text { technology } \\
\text { providers) }\end{array}$ & $7 \mathrm{MS}$ & $\mathrm{X}$ & $\mathrm{X}$ & (1) & $\begin{array}{l}\text { Electricity sector } \\
(2009)\end{array}$ & $\begin{array}{l}\text { Low-carbon technology } \\
\text { Adoption } \\
\text { Low-carbon R\&D }\end{array}$ & $\begin{array}{l}\text { - Perception of EU ETS in } \\
\text { phase } 1-2 \text { /phase } 3\end{array}$ & $\begin{array}{l}\text { Multivariate linear } \\
\text { regression (OLS) }\end{array}$ & $\begin{array}{l}\text { Negative effect of allowance grandfathering on adoption (it even } \\
\text { incentivised emitting technologies). } \\
\text { Non-significant effect of EU ETS perception on adoption of non- } \\
\text { emitting technologies. } \\
\text { Positive effect of perception of long term emission reduction target } \\
\text { on low-carbon R\&D. }\end{array}$ \\
\hline $\begin{array}{l}\text { Lofgren et al. } \\
\text { (2014) }\end{array}$ & $\begin{array}{l}\text { Firms level data } \\
\text { ( } 776 \text { firms of which } \\
229 \text { are regulated) }\end{array}$ & $\begin{array}{l}1 \mathrm{MS} \\
(\mathrm{SE})\end{array}$ & $\mathrm{X}$ & & & $\begin{array}{l}\text { All sectors } \\
\text { included (2000- } \\
\text { 2008) }\end{array}$ & $\begin{array}{l}\text { Low-carbon technology } \\
\text { Adoption }\end{array}$ & $\begin{array}{l}\text { - Participation in the EU ETS } \\
\text { (dummy) } \\
\text { - Proxy of allowance over- } \\
\text { allocation (2) }\end{array}$ & $\begin{array}{l}\text { Difference-in- } \\
\text { Difference }\end{array}$ & $\begin{array}{l}\text { No significant effect of EU ETS implementation on investment } \\
\text { behaviour. } \\
\text { No significant effect of over-allocation on investment behaviour. }\end{array}$ \\
\hline $\begin{array}{l}\text { Bel and Joseph } \\
\text { (2018) }\end{array}$ & Country level data & $28 \mathrm{MS}$ & $\mathrm{X}$ & $\mathrm{X}$ & & $\begin{array}{l}\text { All sectors } \\
\text { included (2005- } \\
\text { 2012) }\end{array}$ & Low-carbon Patents & $\begin{array}{l}\text { - Proxy of allowance over- } \\
\text { allocation (2) }\end{array}$ & $\begin{array}{l}\text { Negative binomial } \\
\text { panel data. }\end{array}$ & Negative effect of allowance over-allocation on low carbon patents. \\
\hline $\begin{array}{l}\text { Borghesi et al. } \\
(2015 \mathrm{a})\end{array}$ & Firm level data & $\begin{array}{l}1 \mathrm{MS} \\
\text { (IT) }\end{array}$ & $\mathrm{X}$ & & & $\begin{array}{l}\text { Manufacturing } \\
\text { firms (2006-2008) }\end{array}$ & $\begin{array}{l}\text { Any environmental } \\
\text { innovation (Survey } \\
\text { question: yes/no) }\end{array}$ & $\begin{array}{l}\text { - Proxy of allowance over- } \\
\text { allocation (2) }\end{array}$ & Probit model & $\begin{array}{l}\text { Negative effect of stringency on innovation (the authors relate this } \\
\text { counterintuitive result to potential anticipatory behaviour of } \\
\text { regulated firms or to reverse causality between allocation and } \\
\text { innovation). }\end{array}$ \\
\hline Calel (2018) & Firm level data & $\begin{array}{l}1 \mathrm{MS} \\
(\mathrm{GB})\end{array}$ & $\mathrm{X}$ & $\mathrm{x}$ & & All sectors & $\begin{array}{l}\text { Low-carbon R\&D } \\
\text { Low-carbon patents } \\
\text { CO2 intensity (proxy of } \\
\text { adoption) }\end{array}$ & $\begin{array}{l}\text { - Participation in the EU ETS } \\
\text { (dummy) }\end{array}$ & Matching estimator & $\begin{array}{l}\text { No significant effect of the EU ETS on regulated companies' carbon } \\
\text { intensity (i.e. no effect on adoption). } \\
\text { Positive effect on low-carbon patenting ( }+25 \% \text { compared to } \\
\text { counterfactual). } \\
\text { Positive effect on low-carbon R\&D spending. }\end{array}$ \\
\hline
\end{tabular}

Notes: (1) Despite data was raised from interviews in 2009, the analysis can be understood to cover phase 1,2 and 3; as the results focus on expectations (Martin et al 2013) or perceptions (Schmidt et al 2012) about

future EU ETS phases. (2) Proxies of allowance over-allocation refer to different set of similar indicators where allocated allowances are contrasted with verified emissions, but not with a counterfactual scenario where firms/countries are allocated differently. We, therefore, refer to this as a proxy to over-allocation rather than to actual over-allocation. 
Table 2 - Summary of non-econometric studies specific to the electricity sector.

\begin{tabular}{|c|c|c|c|c|c|c|c|c|}
\hline Study & Data & MS & $\begin{array}{l}\text { Sector (Year } \\
\text { survey/interview) }\end{array}$ & Research Question & Main Conclusions & $\begin{array}{l}\text { Reported ETS } \\
\text { effect (1) }\end{array}$ & $\begin{array}{l}\text { Type of innovation } \\
\text { identified } \\
\text { (process/product) }\end{array}$ & $\begin{array}{l}\text { ETS influence } \\
\text { level }\end{array}$ \\
\hline Hoffmann (2007) & $\begin{array}{l}\text { Primary } \\
\text { (Interview to } 5 \\
\text { companies that } \\
\text { account for } 80 \% \\
\text { sectorial carbon } \\
\text { emissions) }\end{array}$ & $\begin{array}{l}1 \mathrm{MS} \\
(\mathrm{DE})\end{array}$ & Electricity (2006) & $\begin{array}{l}\text { Which way does the EU ETS } \\
\text { affect technology investment } \\
\text { decisions that reduce } \mathrm{CO} 2 \\
\text { emissions? }\end{array}$ & $\begin{array}{l}\text { - The EU ETS drives small scale investments with short amortization } \\
\text { times; retrofits (key to this was malus rule of the German's NAP), } \\
\text { limited on portfolio choices (fuel choice of new plants), and limited } \\
\text { effect on R\&D investment: } \\
\text { - Investment on renewable not driven by the EU ETS. } \\
\text { - Increased interest on CCS related R\&D, however considered too risky } \\
\text { given carbon price level and its volatility. Public perception is a more } \\
\text { powerful driver. } \\
\text { - The EU ETS did not affect fuel choice for new plants in the portfolio } \\
\text { (other factors more important) } \\
\text { - Organizational changes to control the associated risk with investments } \\
\text { decisions under the EU ETS. } \\
\text { - Effort: } 2-10 \text { million per investment (amortization 2-5 years). }\end{array}$ & $\begin{array}{l}\text { - CCS R\&D. } \\
\text { - Retrofits. }\end{array}$ & $\begin{array}{l}\text { - Organizational (ETS } \\
\text { risk management). }\end{array}$ & - Low to moderate. \\
\hline $\begin{array}{l}\text { Rogge and } \\
\text { Hoffmann (2010) }\end{array}$ & $\begin{array}{l}\text { Primary } \\
\text { ( } 42 \text { interviews) }\end{array}$ & $\begin{array}{l}1 \mathrm{MS} \\
(\mathrm{DE})\end{array}$ & $\begin{array}{l}\text { Electricity } \\
(2006-2009)\end{array}$ & $\begin{array}{l}\text { Which changes in the } \\
\text { electricity's innovation system } \\
\text { have been triggered by the ETS? } \\
\text { (changes in innovation system } \\
\text { include changes in: (i) } \\
\text { Knowledge and technologies, } \\
\text { (ii) actors and networks, } \\
\text { (iii)institutions and (iv) demand) }\end{array}$ & $\begin{array}{l}\text { - Accelerates investment in new and existing plants (specially in coal- } \\
\text { fired plants). } \\
\text { - Significant impact on R\&D in CCS technologies (also seen as a way to } \\
\text { protect investment in existing plants). Strong effect on linkages between } \\
\text { large utilities and technology providers (related with CCS). } \\
\text { - Additional driver for R\&D in energy efficiency (seen as the low risk } \\
\text { option). } \\
\text { - Feed-in-tariff systems are more relevant for R\&D in renewables. } \\
\text { - Incremental increase in the optimal efficiency level of new and existing } \\
\text { plants. }\end{array}$ & $\begin{array}{l}\text { - R\&D. } \\
\text { - Retrofits. }\end{array}$ & $\begin{array}{l}\text { - Process innovation } \\
\text { (increase Energy } \\
\text { efficiency, R\&D on } \\
\text { CCS) }\end{array}$ & - Moderate impact. \\
\hline $\begin{array}{l}\text { Rogge et al. } \\
(2011)\end{array}$ & $\begin{array}{l}\text { Primary } \\
\text { (In depth } \\
\text { interviews to } 61 \\
\text { experts from } 19 \\
\text { power generators, } \\
\text { technology } \\
\text { providers and } \\
\text { project } \\
\text { development). }\end{array}$ & $\begin{array}{l}1 \mathrm{MS} \\
\text { (DE) }\end{array}$ & $\begin{array}{l}\text { Electricity } \\
\text { (2008-2009, when } \\
\text { phase II was } \\
\text { already determined } \\
\text { and phase III details } \\
\text { publicly available). }\end{array}$ & $\begin{array}{l}\text { Which is the effect of the ETS } \\
\text { on R\&D, Adoption and } \\
\text { Organizational change in the } \\
\text { German power sector? }\end{array}$ & $\begin{array}{l}\text { - The EU ETS has led to a significant intensification of R\&D activities } \\
\text { through three routes that can be differentiated in whether the emissions } \\
\text { are captured before (IGCC), during (oxyfuel) or after combustion (post- } \\
\text { combustion). } \\
\text { - Strong increase in corporate CCS research. } \\
\text { - Heterogeneous effects on R\&D for energy efficiency improvements: } \\
\text { High for coal plants (accelerated previously ongoing R\&D) and very } \\
\text { little for gas plants and wind turbines. } \\
\text { - Heterogeneous effects on adoption decisions of new plants: Before full } \\
\text { auctioning, there were perverse incentives for coal plants. For gas plants, } \\
\text { in contrast, no effect was driven by ETS. } \\
\text {-Effects on retrofit of existing plants: The EU ETS contributes to } \\
\text { increase retrofit activities in coal plants. }\end{array}$ & $\begin{array}{l}\text { - R\&D. } \\
\text { - Retrofits } \\
\text { (strong for coal } \\
\text { plants). }\end{array}$ & $\begin{array}{l}\text { - Process innovation } \\
\text { (energy efficiency for } \\
\text { coal plants) } \\
\text { - Organizational } \\
\text { innovation. }\end{array}$ & $\begin{array}{l}\text { - Overall low } \\
\text { effect, but } \\
\text { significant effect } \\
\text { on R\&D (CCS), on } \\
\text { retrofit activities } \\
\text { for coal plants and } \\
\text { on organizational } \\
\text { changes. }\end{array}$ \\
\hline $\begin{array}{l}\text { Schmidt et al. } \\
\text { (2012b) }\end{array}$ & $\begin{array}{l}\text { Primary } \\
\text { (201 firms: } 65 \\
\text { power generators }\end{array}$ & $7 \mathrm{MS}$ & $\begin{array}{l}\text { Electricity } \\
(2009)\end{array}$ & $\begin{array}{l}\text { "How do firms, with diverse } \\
\text { characteristics, differ regarding } \\
\text { their contributions to low- }\end{array}$ & $\begin{array}{l}\text { - Results obtained cast doubts upon whether the current policy mix is } \\
\text { able to trigger the needed acceleration and redirection of technological } \\
\text { change in the magnitude needed to meet the targets. }\end{array}$ & $-\ldots$ & $-\ldots$ & - Low impact. \\
\hline
\end{tabular}




\begin{tabular}{|c|c|c|c|c|c|c|c|c|}
\hline & $\begin{array}{l}\text { and } 135 \text { technology } \\
\text { providers). }\end{array}$ & & & $\begin{array}{l}\text { carbon technological change in } \\
\text { the power sector?" }\end{array}$ & $\begin{array}{l}\text { - Many firms appear to be behaviourally unaffected by climate } \\
\text { regulations (Cluster analysis: BAU cluster, with } 40 \% \text { of the firms, is the } \\
\text { bigger cluster identified). }\end{array}$ & & & \\
\hline $\begin{array}{l}\text { Hervé-Mignucci } \\
\text { (2011) }\end{array}$ & $\begin{array}{l}\text { Secondary data } \\
\text { (Survey of } \\
\text { investments by top } \\
5 \text { carbon } \\
\text { constrained } \\
\text { utilities. Survey } \\
\text { based on official } \\
\text { corporate } \\
\text { communications). }\end{array}$ & EU & $\begin{array}{l}\text { Electricity } \\
(2004-2009)\end{array}$ & $\begin{array}{l}\text { How the EU ETS influenced } \\
\text { longer-term impacts considering } \\
\text { both operating investments and } \\
\text { financial investments in power } \\
\text { generation? }\end{array}$ & $\begin{array}{l}\text { - Since the EU ETS came into force, some investments made are clearly } \\
\text { in favor of mitigating emissions (although this cannot be attributed to the } \\
\text { ETS). } \\
\text { - "The tighter constraint in phase II and expected phase III triggered } \\
\text { clear investment related responses: highly carbon-emitting plants } \\
\text { cancelled in favor of plants emitting less } \mathrm{CO}_{2} \text { or regulated entities fully } \\
\text { using offset project mechanisms to foster investments in lower carbon } \\
\text { power plants." }\end{array}$ & $\begin{array}{l}\text { - Cancellation } \\
\text { of projected } \\
\text { highly emitting } \\
\text { plants. }\end{array}$ & - Process innovation. & $\begin{array}{l}\text { - Moderate effect } \\
\text { (because of plant } \\
\text { cancellations } \\
\text { identified). }\end{array}$ \\
\hline
\end{tabular}

Notes: (1) Only reported innovation activities that according to the study were entirely or partially induced by the EU ETS.

Table 3 - Summary of non-econometric studies relevant to sectors other than electricity.

\begin{tabular}{|c|c|c|c|c|c|c|c|c|}
\hline Study & Data & MS & $\begin{array}{l}\text { Sector (Year } \\
\text { survey/interview) }\end{array}$ & Research Question & Main Conclusions & $\begin{array}{l}\text { Reported ETS } \\
\text { effect (1) }\end{array}$ & $\begin{array}{l}\text { Kind of innovation } \\
\text { identified } \\
\text { (process/product) }\end{array}$ & $\begin{array}{l}\text { ETS influence } \\
\text { level }\end{array}$ \\
\hline Pontoglio (2008) & $\begin{array}{l}\text { Primary } \\
\text { (Survey with } 38 \\
\text { respondents). }\end{array}$ & $\begin{array}{l}1 \mathrm{MS} \\
\text { (IT) }\end{array}$ & $\begin{array}{l}\text { Paper Industry } \\
(2006) \text {. }\end{array}$ & $\begin{array}{l}\text { Which is the role of EU ETS as } \\
\text { driving factor for eco- } \\
\text { innovations? }\end{array}$ & $\begin{array}{l}\text { - The majority of the respondents ( } 52 \%) \text { declared not to have } \\
\text { realized/planned to introduce technological innovations aimed at } \\
\text { reducing emissions. The remaining }(48 \%) \text { already realized or developed } \\
\text { projects for the coming years. As for the innovation typology, } 38 \% \\
\text { were energy-efficient solutions; } 24 \% \text { were directed at the optimisation of } \\
\text { the production process. } \\
\text { - Italian paper plants are old on average, and hence there are significant } \\
\text { margins for improving efficiency (in energy and the use of raw } \\
\text { materials). } \\
\text {-Energy prices are more relevant in driving energy efficiency than } \\
\text { uncertain carbon prices. }\end{array}$ & $-\cdots$ & $-\ldots$ & $\begin{array}{l}\text { - Low or null } \\
\text { impact. }\end{array}$ \\
\hline $\begin{array}{l}\text { Tomas et al. } \\
\text { (2010) }\end{array}$ & \begin{tabular}{|l} 
Primary \\
(Survey with 4 \\
representative \\
firms). \\
\end{tabular} & $\begin{array}{l}1 \mathrm{MS} \\
(\mathrm{PT})\end{array}$ & Chemical Industry. & $\begin{array}{l}\text { How did the EU ETS affect the } \\
\text { cost structure of the Portuguese } \\
\text { chemical industry? }\end{array}$ & $\begin{array}{l}\text { - Limited impact: The cost increases observed were found to be non- } \\
\text { relevant. } \\
\text { - Grandfathering and low prices cannot act as a stimulus for innovation. }\end{array}$ & $-\ldots$ & $-\ldots$ & $\begin{array}{l}\text { - Low or null } \\
\text { impact. }\end{array}$ \\
\hline $\begin{array}{l}\text { Anderson et al. } \\
\text { (2011) }\end{array}$ & $\begin{array}{l}\text { Primary } \\
\text { (Mail interviews to } \\
27 \text { firms, } 70 \% \text { of } \\
\text { the Irish allowance } \\
\text { allocation). }\end{array}$ & $\begin{array}{l}1 \mathrm{MS} \\
(\mathrm{IR})\end{array}$ & $\begin{array}{l}\text { All regulated } \\
\text { sectors. }\end{array}$ & $\begin{array}{l}\text { How did to the ETS affect } \\
\text { technological changes in terms } \\
\text { of: } \\
\text { - machinery and equipment } \\
\text { adoption, } \\
\text { - process or behavioral change } \\
\text { using existing equipment, }\end{array}$ & $\begin{array}{l}\text { - } 48 \% \text { of the respondents report technology adoption. However the EU } \\
\text { ETS, despite considered, is not the main driver (rising energy prices } \\
\text { more important). } \\
-74 \% \text { report some form of process/behavioural change with current } \\
\text { machinery, of which } 30 \% \text { admit some influence (marginal or strong) } \\
\text { driven by the EU ETS. } \\
-41 \% \text { engaged in fuel switching "in order to reduce carbon emissions". }\end{array}$ & $\begin{array}{l}\text { - Technology } \\
\text { adoption. } \\
\text { - Behavioural } \\
\text { change. } \\
\text { - Fuel } \\
\text { switching. }\end{array}$ & $\begin{array}{l}\text { - Process innovation } \\
\text { (some technological } \\
\text { adoption, process } \\
\text { changes and fuel } \\
\text { switching). }\end{array}$ & - Moderate impact. \\
\hline
\end{tabular}




\begin{tabular}{|c|c|c|c|c|c|c|c|c|}
\hline & & & & $\begin{array}{l}\text { - fuel switching and } \\
\text { - R\&D investments }\end{array}$ & $\begin{array}{l}\text { - 46\% report that the EU ETS had influenced the way in which capital } \\
\text { and investments are analysed. }\end{array}$ & & & \\
\hline $\begin{array}{l}\text { Rogge et al. } \\
(2011)\end{array}$ & $\begin{array}{l}\text { Primary } \\
\text { (Survey among } \\
\text { paper producers } \\
\text { (19) and } \\
\text { technology } \\
\text { providers (17)). }\end{array}$ & $\begin{array}{l}1 \mathrm{MS} \\
(\mathrm{DE})\end{array}$ & $\begin{array}{l}\text { Paper Industry. } \\
(2008-2009)\end{array}$ & $\begin{array}{l}\text { How did the EU ETS affect the } \\
\text { innovation activities of: R\&D, } \\
\text { Adoption (investment in new } \\
\text { plants or modernization of } \\
\text { existing ones) and } \\
\text { Organizational change } \\
\text { (procedural, structural or vision } \\
\text { change) in the German Paper } \\
\text { Industry? }\end{array}$ & $\begin{array}{l}\text { - Innovation activities are mainly driven by market forces other than the } \\
\text { EU ETS. } \\
\text { - The EU ETS has a low relevance for R\&D investment: It is considered } \\
\text { the least relevant factor (More important are: the prices of paper, raw } \\
\text { material and fuel, and public acceptance). } 65 \% \text { of paper producers } \\
\text { consider the EU ETS has low relevance and only } 21 \% \text { high relevance } \\
\text { (lower } \% \text { for tech-providers). } \\
\text { - Market factors are more relevant for adoption decisions. Although } 37 \% \\
\text { considered the EU ETS of high relevance in adoption decisions. } \\
\text { - Regulated companies have performed more } \mathrm{CO}_{2} \text {-related organizational } \\
\text { changes than non-regulated companies have. }\end{array}$ & $\begin{array}{l}\text { - R\&D. } \\
\text { - Adoption. } \\
- \\
\text { Organizational. }\end{array}$ & $\begin{array}{l}\text { - Process innovation } \\
\text { (mainly organizational). }\end{array}$ & $\begin{array}{l}\text {-Null or very low } \\
\text { impact. Only } \\
\text { moderate for } \\
\text { Organizational } \\
\text { Innovations. }\end{array}$ \\
\hline $\begin{array}{l}\text { Gasbarro, Rizzi, } \\
\text { Frey (2013) }\end{array}$ & $\begin{array}{l}\text { Primary } \\
\text { ( } 6 \text { case studies that } \\
\text { include } 24 \\
\text { installations). }\end{array}$ & $\begin{array}{l}1 \mathrm{MS} \\
(\mathrm{IT})\end{array}$ & $\begin{array}{l}\text { Pulp and paper } \\
\text { Industry } \\
(2010-2011)\end{array}$ & $\begin{array}{l}\text { How did the EU ETS influence } \\
\text { companies' Environmental } \\
\text { Management Systems (EMS) } \\
\text { and to what extend did it affect } \\
\text { investment planning of the pre- } \\
\text { existing EMS program? }\end{array}$ & $\begin{array}{l}\text { - Companies having an EMS better integrate GHG emission monitoring } \\
\text { and compliance within the existing organization. } \\
\text { - But cost reduction (and factors other than the EU ETS) is the main } \\
\text { driver of investment decisions. } \\
\text { - "Investments in technological innovation to reduce carbon emissions } \\
\text { are still limited, and investments tend to be mainly focused on market- } \\
\text { available technologies for core processes." (In any case, not driven by } \\
\text { the ETS). } \\
\text { - "The EU ETS has not been able to trigger additional investment in } \\
\text { technological innovation, despite the presence of an EMS". }\end{array}$ & $-\ldots$ & $-\ldots$ & - Null effect \\
\hline $\begin{array}{l}\text { Gulbrandsen and } \\
\text { Stenqvist (2013) }\end{array}$ & $\begin{array}{l}\text { Primary } \\
\text { ( } 2 \text { case studies). }\end{array}$ & $\begin{array}{l}2 \text { Contr. } \\
\text { (SE, } \\
\text { NO) }\end{array}$ & $\begin{array}{l}\text { Pulp and Paper } \\
\text { Industry } \\
(2012)\end{array}$ & $\begin{array}{l}\text { How have the EU ETS } \\
\text { influenced the climate strategies } \\
\text { of two Nordic pulp and paper } \\
\text { companies? }\end{array}$ & $\begin{array}{l}\text { - The EU ETS had a rather limited effect on the climate strategies. } \\
\text { - EUA price is too low and allowances too abundant to underpin } \\
\text { investment decisions. } \\
\text { - However, increase of energy prices (perceived as the strongest } \\
\text { influence of the EU ETS) have reinforced some long-term commitments } \\
\text { to improve energy efficiency and reduce emissions, i.e. greater interest } \\
\text { for own power assets. }\end{array}$ & $-\ldots$ & $-\ldots$ & $\begin{array}{l}\text { - Low or null } \\
\text { effect. }\end{array}$ \\
\hline $\begin{array}{l}\text { Borghesi et al } \\
(2015 b)\end{array}$ & $\begin{array}{l}\text { Primary } \\
\text { ( } 29 \text { interviews to } \\
\text { industry } \\
\text { associations, other } \\
\text { experts or industry } \\
\text { representatives). }\end{array}$ & $\begin{array}{l}8 \mathrm{MS} \\
\text { (CZ, PL, } \\
\text { IT, DE, } \\
\text { GB, ES, } \\
\text { FR, NL) }\end{array}$ & $\begin{array}{l}6 \text { sectors: energy, } \\
\text { ceramics, cement, } \\
\text { paper, coke and } \\
\text { refinery } \\
(2013)\end{array}$ & $\begin{array}{l}\text { Did policy support drive eco- } \\
\text { innovations in terms of (i) } \\
\text { technological and (ii) } \\
\text { organizational innovations over } \\
\text { the period 2000-2012? }\end{array}$ & $\begin{array}{l}\text { - Energy: The EU ETS did not contribute much to technology } \\
\text { innovation in large combustion plants, but promoted fuel switching, } \\
\text { CCS related innovations and organizational innovations. } \\
\text { - Ceramics and cement: innovations driven by market factors, not by } \\
\text { policy. } \\
\text { - Paper: innovation driven by energy costs. Possible incremental } \\
\text { influence of the EU ETS on already ongoing innovation projects. } \\
\text { - Coke and refinery: Past policies were more relevant for innovation than } \\
\text { the EU ETS. }\end{array}$ & $\begin{array}{l}\text { - Fuel } \\
\text { switching. } \\
\text { - CCS projects. }\end{array}$ & $\begin{array}{l}\text { - Process innovation } \\
\text { (energy). } \\
\text { - Organizational } \\
\text { innovation (energy). }\end{array}$ & $\begin{array}{l}\text { - Moderate effect } \\
\text { (energy). } \\
\text { - Very low or null } \\
\text { effect (the } \\
\text { remaining sectors) }\end{array}$ \\
\hline
\end{tabular}




\begin{tabular}{|c|c|c|c|c|c|c|c|c|}
\hline Venmans (2016) & $\begin{array}{l}\text { Primary } \\
\text { (In-depth interview } \\
\text { to } 16 \text { managers). }\end{array}$ & $\begin{array}{l}1 \mathrm{MS} \\
\text { (BE) }\end{array}$ & $\begin{array}{l}\text { Ceramics, lime and } \\
\text { cement } \\
(2012)\end{array}$ & $\begin{array}{l}\text { How do managers perceive } \\
\text { (free) allowance allocation } \\
\text { above emissions in terms of } \\
\text { incentives to invest in } \\
\text { abatement? }\end{array}$ & $\begin{array}{l}\text {-The vast majority of them thought that allocation below emissions was } \\
\text { a greater incentive to invest. "Companies combusting natural gas stated } \\
\text { the availability of excess permits as the main reason for not including } \\
\text { the carbon advantage of efficiency investments when assessing payback } \\
\text { values." } \\
\text { - Price uncertainty was perceived as a risk to be minimized, and hence, } \\
\text { an incentive for low carbon investment. "Avoiding uncertainty from the } \\
\text { EU ETS was an important motivation to invest in energy efficiency, } \\
\text { certainly for future projects when companies are likely to be allocated } \\
\text { below emissions". However, when the price volatility is faced directly, } \\
\text { certain price vs uncertain price, most perceived uncertainty as a } \\
\text { disincentive. }\end{array}$ & - & $-\ldots$ & $-\ldots$ \\
\hline $\begin{array}{l}\text { Petsonk and } \\
\text { Cozijnsen (2007) }\end{array}$ & $\begin{array}{l}\text { Secondary data } \\
\text { (Case studies: } \\
\text { description of three } \\
\text { cases that were } \\
\text { possible because of } \\
\text { the EU ETS } \\
\text { existence). }\end{array}$ & $\begin{array}{l}3 \mathrm{MS} \\
\text { (NE, } \\
\mathrm{DE}, \mathrm{FR})\end{array}$ & All sectors & $\begin{array}{l}\text { How does the EU ETS stimulate } \\
\text { the technological and process } \\
\text { innovations? }\end{array}$ & $\begin{array}{l}\text { - Carbon emissions from a refinery are used by horticulture farmers, } \\
\text { who otherwise would have needed to burn gas (to generate fertilizer). } \\
\text { This already known technology only became economical once carbon } \\
\text { had a price. } \\
\text { - Methane captures and generation of renewable energy are becoming } \\
\text { more profitable thanks to the EU ETS. }\end{array}$ &..- & - Process innovation. & - Strong effect. \\
\hline $\begin{array}{l}\text { Fontini and } \\
\text { Pavan (2014) }\end{array}$ & $\begin{array}{l}\text { Secondary data } \\
\text { (173 Italian paper } \\
\text { plants). }\end{array}$ & $\begin{array}{l}1 \mathrm{MS} \\
\text { (IT) }\end{array}$ & $\begin{array}{l}\text { Paper and pulp } \\
\text { industry } \\
(2005-2010)\end{array}$ & $\begin{array}{l}\text { Index decomposition of the } \\
\text { variation in emission in terms of } \\
\text { composition, technic and scale } \\
\text { effects. }\end{array}$ & $\begin{array}{l}\text { - In phase I, there was a reduction emission via composition effect: shift } \\
\text { in production towards products that cause less carbon emissions. This } \\
\text { trend could be driven by either change in production or change in } \\
\text { demand. } \\
\text { - In phase II, technological change played a contribution, but the scale } \\
\text { effect (decrease in overall output) always dominated emission reduction, } \\
\text { in both phases I and II. }\end{array}$ & $-\ldots$ & $-\ldots$ & $\begin{array}{l}\text { - Low effect } \\
\text { (potentially only, as } \\
\text { the method does } \\
\text { not allow to } \\
\text { identify the EU } \\
\text { ETS effect). }\end{array}$ \\
\hline
\end{tabular}

Notes: (1) Only reported innovation activities that according to the study were entirely or partially induced by the EU ETS. 
Table 4 - Effects of the EU ETS on innovation and adoption of low-carbon technologies (econometric literature).

\begin{tabular}{|c|c|c|}
\hline & \multicolumn{2}{|c|}{ Effect of the EU ETS } \\
\hline Study & $\begin{array}{c}\text { Innovation } \\
\text { (Low-carbon R\&D or patenting) } \\
\end{array}$ & $\begin{array}{c}\text { Adoption } \\
\text { (Investment in existing low-carbon technologies) }\end{array}$ \\
\hline Schmidt et al. (2012a) & $+(\mathrm{R} \& \mathrm{D})$ & \\
\hline Schmidt et al. (2012a) & & 0 \\
\hline Martin et al. (2013) & 0 (R\&D) & \\
\hline Lofgren et al. (2014) & & 0 \\
\hline Borghesi et al. (2015a) & & + \\
\hline Calel and Dechezlepretre (2016) & + (Patenting) & \\
\hline Calel (2018) & $+(\mathrm{R} \& \mathrm{D})$ & \\
\hline Calel (2018) & + (Patenting) & \\
\hline
\end{tabular}

Figure 1 - Spot price of European emission allowances (settlement price).

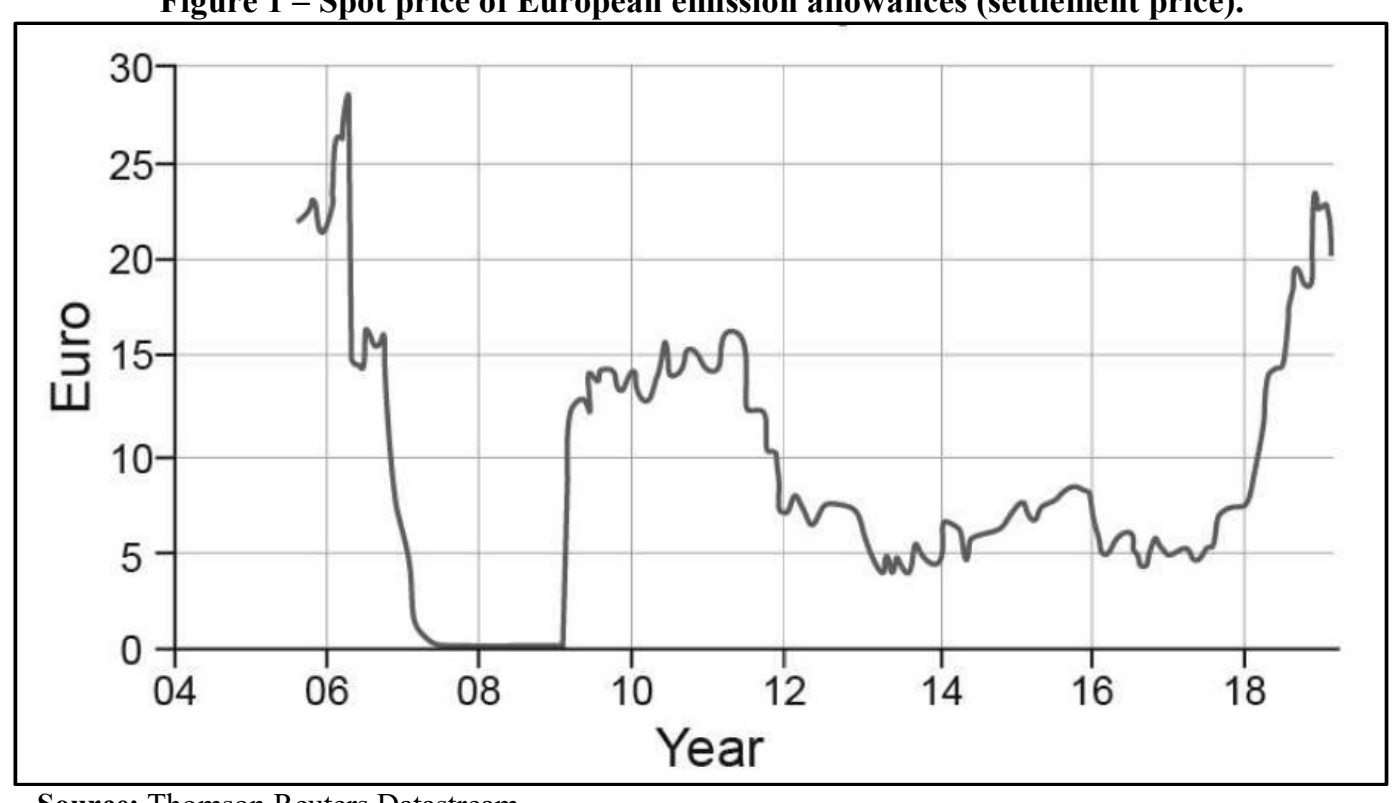

Source: Thomson Reuters Datastream. 